\title{
O PACOTE ANTICRIME E SEUS IMPACTOS NO SISTEMA ACUSATÓRIO BRASILEIRO: A CONSTITUCIONALIDADE DO ARTIGO 385, DO CPP NA JURISPRUDÊNCIA DOS TRIBUNAIS
}

\author{
Roberto Carvalho Veloso ${ }^{1}$ \\ André Márcio Costa Nogueira ${ }^{2}$
}

\section{RESUMO}

A jurisprudência do Superior Tribunal de Justiça e Supremo Tribunal Federal precisam rapidamente alinhar-se à nova tendência do sistema acusatório brasileiro superando seus precedentes que ainda emprestam constitucionalidade ao artigo 385, do Código de Processo Penal apesar da recente mudança promovida pela Lei 13.694/2019. Desse modo, por meio de pesquisa documental e teórica-bibliográfica, propõe-se uma reflexão sobre os argumentos que ainda sustentam a constitucionalidade do artigo 385, do Código de Processo Penal em face das mudanças promovidas pela Lei 13.694/2019, modificando os poderes instrutórios do juiz em razão dessa nova realidade legislativa.

Palavras chave: processo penal. sistema acusatório. pacote anticrime. Inconstitucionalidade. Poderes instrutórios do juiz.

\section{THE ANTICRIME PACKAGE AND ITS IMPACTS ON THE BRAZILIAN ACCUSATORY SYSTEM: THE CONSTITUTIONALITY OF ARTICLE 385, OF THE CPP IN THE JURISPRUDENCE OF THE COURTS}

\begin{abstract}
The jurisprudence of the Superior Court of Justice and the Federal Supreme Court need to quickly align with the new trend of the Brazilian accusation system, overcoming its precedents that still lend constitutionality to article 385 of the Code of Criminal Procedure despite the recent change promoted by Law 13.694/2019. Thus, through documentary and theoretical-bibliographic research, it is proposed a reflection on the arguments that still support the constitutionality of article 385 of the Code of Criminal Procedure in view of the changes promoted by Law 13.694/2019, modifying the instructive powers of the judge due to this new legislative reality.

Key-words: criminal proceedings; accusatory system; anti-crime package; Unconstitutionality; Instructory powers of the judge.
\end{abstract}

\section{INTRODUÇÃO}

\footnotetext{
${ }^{1}$ Doutor e Mestre em Direito pela Universidade Federal de Pernambuco. Docente e Pesquisador do Programa de Pós-Graduação em Direito e Instituições do Sistema de Justiça/UFMA. Coordenador do Programa de PósGraduação em Direito e Instituições do Sistema de Justiça/UFMA. E-mail: velosorc@uol.com.br

${ }^{2}$ Mestrando em Direito e Instituições do Sistema de Justiça da Universidade Federal do Maranhão, Especialista em Direito Penal e Processo Penal pela Universidade Estácio de Sá/RJ, bacharel em Direito pela Universidade Federal do Maranhão, Professor da Faculdade Santa Terezinha - CEST e Procurador Federal - AGU. Email: andremcnogueira@gmail.com
} 
O processo penal brasileiro é reconhecidamente um dos ramos do direito público que mais experimentou mudanças paradigmáticas nos últimos anos, embora devemos reconhecer que a Constituição Federal de 1988 tenha iniciado esse processo de importantes alterações do perfil autoritário do vetusto Código de Processo Penal.

Nesse contexto de mudanças, cumpre destacar a recente publicação da Lei $n^{\circ}$ 13.694/2019, conhecida popularmente como pacote anticrime e a produção jurisprudencial dos Tribunais Superiores que, como sabido foi confiada a missão de guardiões da interpretação da Constituição e da legislação federal, o que os transformou em protagonistas de parte das inquietações e perplexidades.

Nessa ordem de valores, percebemos que o pacote anticrime visou promover uma maior aproximação da legislação infraconstitucional com a Constituição Federal de 1988 e, no que interessa à presente pesquisa, revolucionará o papel institucional do Ministério Público e do Poder Judiciário no contexto de um processo penal democrático, eficiente e garantista, trazendo expressamente a previsão de um processo penal com estrutura acusatória, vedada a intervenção judicial na determinação da prova e a substituição do órgão ministerial.

Além dessa importante alteração no nosso processo penal, devemos também destacar a criação do Juiz de Garantias, a previsão do Acordo de não persecução penal, promovendo um aumento do espaço de consenso, o que obriga-nos concluir pela mitigação da obrigatoriedade da ação penal pública, a promoção direta do arquivamento do inquérito policial ou das peças de informação pelo Ministério Público de modo a fulminar a antiquada função anômala de controle desse ato pelo Poder Judiciário, em meio a outras mudanças incorporadas ao Código Penal e à Lei de Execuções Penais, à título de lembrança.

Esse conjunto de novas e ousadas normas trazidas a reboque no chamado pacote anticrime despertarão grandes desafios e perplexidades, de modo que diversos questionamentos surgirão a partir da circunstância do legislador, como de costume, não ter se louvado da boa técnica legislativa para revogar os eventuais dispositivos em conflito, o que certamente trará muitas dúvidas quanto à sua aplicabilidade aumentando a insegurança jurídica. 
Esses desafios deverão entrar nas pautas dos Tribunais e das demais instâncias do sistema de Justiça e caberá à doutrina e jurisprudência pátria responder aos questionamentos surgidos e aos problemas emergentes dessa nova realidade.

Por óbvio, dentro dos limites que a presente pesquisa impõe é necessário delimitar a apreciação dos temas e objetivamente propor reflexões de modo a trazer algumas considerações e apontar sugestões a partir do manancial teórico existente.

A partir do que foi exposto indaga-se: após a entrada em vigor da Lei $\mathrm{n}^{\circ}$ 13.694/2019, o artigo 385, do Código de Processo Penal continua compatível com o sistema acusatório? Nesse contexto, exsurge necessária uma revisão da jurisprudência dos Tribunais Superiores?

Nesse sentir, utilizando-se a metodologia de uma pesquisa documental, teóricobibliográfica e qualitativa, o presente artigo científico tem como objetivo verificar os argumentos desenvolvidos na jurisprudência do Superior Tribunal de Justiça e do Supremo Tribunal Federal, por meio da análise de julgados e em seguida fazer uma abordagem específica sobre a (in)constitucionalidade do artigo 385, do Código de Processo Penal para no final propor reflexões e sugestões sobre a compatibilização dessa norma no contexto da realidade processual penal brasileira.

\section{PRECEDENTES DO SUPREMO TRIBUNAL FEDERAL E DO SUPERIOR TRIBUNAL DE JUSTIÇA SOBRE A (IN)CONSTITUCIONALIDADE DO ARTIGO 385 DO CÓDIGO DE PROCESSO PENAL}

O desenvolvimento da presente inicia com a demonstração da pesquisa e análise de alguns precedentes do Supremo Tribunal Federal e do Superior Tribunal de Justiça, a partir do acesso direto ao sítio desses Tribunais na rede mundial de computadores, utilizando como chave de pesquisa o artigo 385, do Código de Processo Penal, e as expressões “"pedido" e "absolvição" como filtros adicionais. Como se tratou de pesquisa com termos específicos, o número de resultados obtidos não foi numeroso.

Nesse sentido, no Supremo Tribunal Federal foram encontrados 2 (dois) acórdãos e no Superior Tribunal de Justiça, por sua vez, foram obtidos 28 (vinte e oito) acórdãos. 
O segundo passo consistiu em verificar, dentre os precedentes encontrados, a partir dos dados básicos registrados, a data do julgamento e os fundamentos do voto do(a) Ministro(a) Relator(a) de modo a averiguar se no acórdão foi ou não enfrentado o tema da (in)constitucionalidade do artigo 385, do Código de Processo Penal e qual foi(ram) os argumentos utilizados para declarar a eiva ou entende-la inexistente.

Outro critério, não menos importante da pesquisa, foi selecionar tão somente os julgamentos mais recentes, de preferência, aqueles proferidos após a entrada em vigor da Lei $\mathrm{n}^{\mathrm{o}}$ 13.694/2019, de modo a verificar se o artigo $3^{\circ}$-A, do Código de Processo Penal com a redação que foi dada por aquela lei, foi ou não considerado como vetor interpretativo da decisão.

$\mathrm{Na}$ análise buscou-se verificar se o argumento deduzido encontra ressonância na doutrina pátria de modo a valorar a sua legitimidade frente aos postulados de um sistema acusatório.

Com efeito, na pesquisa realizada no sítio do Supremo Tribunal Federal, de acordo com os parâmetros acima, destacou-se o Agravo Regimental no HC no 185.835/SP, da $1^{\text {a }}$ Turma, cuja Relatoria coube ao eminente Ministro Alexandre de Moraes, julgado por maioria, em 05/08/2020, sendo vencido o Ministro Marco Aurélio, cuja ementa segue transcrita abaixo:

Ementa: HABEAS CORPUS. TRÁFICO DE DROGAS. PACIENTE
CONDENADO EM PRIMEIRA INSTÂNCIA. PARECER DA PROCURADORIA
DE JUSTIÇA PELA ABSOLVIÇÃO. SENTENÇA MANTIDA PELO
TRIBUNAL. POSSIBILIDADE. LIVRE CONVENCIMENTO MOTIVADO.
CONCLUSÃO DIVERSA. NECESSIDADE DO REEXAME DE PROVAS.
INADEQUAÇÃO DA VIA ELEITA. 1. Vigora no sistema processual penal pátrio,
como regra, o sistema do livre convencimento motivado ou da persuasão racional,
segundo o qual o magistrado tem ampla liberdade para valorar as provas que lhe são
apresentadas, desde que o faça de forma fundamentada, isto é, deve motivar sua
decisão, no sentido de condenar ou absolver o acusado, com amparo no acervo
probatório constante dos autos. 2. Nesse contexto, o parecer do Ministério Público,
apresentado em segundo grau de jurisdição, não deve conduzir, necessariamente, à
absolvição do paciente se a instância a quo entendeu, pela avaliação do conjunto
probatório, que existem elementos suficientes para a condenação. Precedente. 3. As
instâncias ordinárias concluíram que o conjunto probatório amealhado na instrução
criminal é apto a justificar o édito condenatório. Logo, para se chegar à conclusão
diversa, seria necessário o reexame da matéria, providência incompatível com esta
via processual. Precedentes. 4 . Agravo regimental a que se nega provimento.


(HC 185835 AgR, Relator(a): ALEXANDRE DE MORAES, Primeira Turma, julgado em 05/08/2020, PROCESSO ELETRÔNICO DJe-204. DIVULG 14-082020 PUBLIC 17-08-2020)

Do Superior Tribunal de Justiça, por sua vez, destacou-se o AgRg nos EDcl no HC 537251 / SP, da 5 ${ }^{\text {a }}$ Turma, com Relatoria do Ministro Néfi Cordeiro, julgado em 12/05/2020. Desse julgado, sobressai a compreensão no sentido de que o artigo 385 , do Código de Processo Penal foi recepcionado pela Constituição Federal de 1988. Esse julgado teve a seguinte ementa:

AGRAVO REGIMENTAL NOS EMBARGOS DE DECLARAÇÃO NO HABEAS CORPUS. ROUBO MAJORADO. PRINCÍPIO DA IDENTIDADE FÍSICA DO JUIZ. RELATIVIDADE. PEDIDO DE ABSOLVIÇÃO PELO MINISTÉRIO PÚBLICO. CONDENAÇÃO. POSSIBILIDADE. ART. 385 DO CÓDIGO DE PROCESSO PENAL. AÇÃO PENAL PÚBLICA. REGIME MAIS GRAVOSO. FUNDAMENTO IDÔNEO. WRIT DENEGADO. DECISÃO MANTIDA. AGRAVO IMPROVIDO.

1. A decisão agravada deve ser mantida por seus próprios fundamentos, pois em consonância com a jurisprudência desta Corte.

2. Admite-se a mitigação do princípio da identidade física do juiz, a fim de possibilitar o julgamento por juiz substituto, quando o magistrado que presidiu o feito se encontrar de férias. Ademais, para que haja o reconhecimento da nulidade por ofensa a esse princípio, faz-se necessária a comprovação de efetivo prejuízo à parte, o que não ocorreu na hipótese.

3. Nos termos do art. 385 do Código de Processo Penal, nos crimes de ação pública, o juiz poderá proferir sentença condenatória, ainda que o Ministério Público tenha opinado pela absolvição.

4. A prática de agressão física contra a vítima não constitui elementar do tipo penal de roubo e é considerada motivação idônea para o agravamento do regime prisional. Precedentes.

5. Agravo regimental improvido.

(AgRg nos EDcl no HC 537.251/SP, Rel. Ministro NEFI CORDEIRO, SEXTA TURMA, julgado em 12/05/2020, DJe 18/05/2020)

Entretanto, importante consignar a análise do conjunto de julgados encontrados, com base nos posicionamentos das 2 (duas) turmas do Superior Tribunal de Justiça, de modo a obter uma visão mais homogênea do entendimento de seus Ministros ao longo de determinado período.

Em resumo, podemos sublinhar que 2 (duas) razões principais aparecem: 
a) A primeira, no sentido de que o magistrado não estaria vinculado ao posicionamento do membro do Ministério Público, em sede de alegações finais, pela absolvição e, portanto, estaria livre para apreciar os fatos e as provas com apoio no livre convencimento motivado, podendo, portanto, proferir um édito condenatório.

b) A segunda, também encontrada nos julgados mais antigos, sustenta que nosso sistema processual penal não segue os postulados de um sistema acusatório puro. Aduzem que, no Brasil, diferente de países de tradição anglo-saxônica, filiados ao sistema do Common Law, o Ministério Público não gozaria de ampla discricionariedade, de modo que poderia não poderia dispor da acusação, portanto reforçando o chamado princípio da obrigatoriedade da ação penal pública.

Na maioria dos casos pesquisados, abrangendo os julgados das 2 (duas) Cortes de Vértice, foi invocado o princípio do livre convencimento motivado do juiz para determinar a proclamação de sentença condenatória, além de existir uma espécie de padrão redacional entre os mesmos e, no caso do Superior Tribunal de Justiça, ainda que prolatado por Ministros ou Turmas diferentes.

Como acima afirmamos, depreende-se dos julgados claro destaque aos princípios da obrigatoriedade e da indisponibilidade da ação penal pública no sentido que ordinariamente os tradicionais manuais de processo penal apresentam, ou seja, no sentido mencionado por Lima (2020) de que não poderá o membro do Ministério Público, uma vez instaurado o processo penal mediante apresentação de denúncia, havendo elementos indiciários que aponte autoria e materialidade, deixar de promover a ação penal pública e de dar regular prosseguimento.

Por derradeiro, cumpre observar ainda que nos 2 (dois) casos destacados acima, em nenhum deles, os Ministros consideraram em seus votos a novel disposição trazida pela 
norma do artigo $3^{\circ}$-A do Código de Processo Penal, na redação dada pela Lei no $13.694 / 2019^{3}$, muito menos percebe-se uma abordagem crítica e sistemática das normas que estavam paradoxalmente transformando nosso processo penal.

Nessa ordem de pensamento, Tourinho Filho (2018) destaca que os princípios da obrigatoriedade e da indisponibilidade da ação penal pública experimentaram importantes mitigações a partir da Lei no 9.099/95, como seus institutos despenalizadores da composição dos danos civis (artigo 72), transação penal (artigo 76) e suspensão condicional do processo (artigo 89), isso no que diz respeito às infrações penais de menor potencial ofensivo (artigo 61, da Lei $n^{\circ}$ 9.099/95).

Por outro lado, com o aumento dos espaços de consenso no processo penal brasileiro, especialmente com os institutos da colaboração premiada previsto no artigo $3^{\circ}$, da Lei $\mathrm{n}^{\circ} 12.850 / 2013$, com as alterações promovidas pelo pacote anticrime, para os crimes praticados por organizações criminosas, portanto no campo da macrocriminalidade, de modo a abarcar condutas como a Lavagem de dinheiro, a corrupção de agentes de públicos, e o novel acordo de não persecução penal, trazido para o código de processo penal no artigo 28-A pela Lei $n^{\circ}$ 13.694/2019 (pacote anticrime), de modo a abarcar condutas criminosas que se qualificariam de média potencialidade lesiva, podemos afirmar que uma maioria expressiva de condutas tipificadas pelo legislador estaria fora das amarras da obrigatoriedade e indisponibilidade da ação penal pública.

Com efeito, nos julgados pesquisados, a ausência de uma análise sistemática da legislação penal e processual penal poderia ser melhor compreendida em face do deferimento da medida cautelar nas 4 (quatro) ações diretas de constitucionalidade pelo Ministro Luiz Fux para suspender essa regra, no bojo da previsão do chamado Juiz de Garantias.

Colocadas as premissas que informam a jurisprudência objeto de avaliação nesta pesquisa, faremos considerações sobre a pertinência ou não dos argumentos expendidos.

\section{DA ADOÇÃO DO SISTEMA ACUSATÓRIO E A SUPERAÇÃO DA OBRIGATORIEDADE E INDISPONIBILIDADE DA AÇÃO PENAL PÚBLICA}

\footnotetext{
${ }^{3}$ Importante consignar que a decisão liminar proferida nas ADI's 6298, 6299, 6300 6305, no dia 22/01/2020, do Ministro Luiz Fux suspenderam a eficácia do artigo 3º-A, do Código de Processo Penal.
} 
A Constituição Federal de 1988 não possui dispositivo expresso no sentido de oferecer claramente uma escolha pelo sistema acusatório, opção que é dedutível a partir da previsão das instituições do sistema de Justiça brasileira com suas respectivas funções.

Do contexto das normas magnas destaca-se o artigo 129, inciso I, que diz competir ao Ministério Público a ação penal pública na forma da lei. Assevera a doutrina que se trata de norma que assegura a titularidade da ação penal pública ao parquet. Essa mesma norma repete-se no artigo 24, do Código de Processo Penal.

Sem embargo, o texto constitucional atribui excepcionalmente ao ofendido a possibilidade de deflagrar a ação penal caso o órgão ministerial não promova a denúncia no prazo legal, havendo justa causa para fazê-lo. Trata-se de norma fundamental insculpida no artigo $5^{\circ}$, inciso LIX, da Constituição Federal.

O artigo $3^{\mathrm{a}}$-A do Código de Processo Penal com a redação dada pela Lei $\mathrm{n}^{\circ}$ 13.694/2019, inovou o quadro normativo infraconstitucional ao prescrever que o processo penal terá estrutura acusatória, vedadas a iniciativa do juiz na fase de investigação e a substituição da atuação probatória do órgão de acusação.

Antes dessa norma, não havia nenhuma que dispusesse expressamente sobre norma geral de processo penal e, ao que parece, trata o legislador de firmar uma premissa geral a informar o sistema processual penal brasileiro.

Por sua vez, o artigo 42, do Código de Processo Penal asseverou que o Ministério Público não poderá desistir da ação penal. Da mesma maneira, prescreveu o artigo 32, do Código de Processo Penal Militar no sentido de que apresentada a denúncia, o Ministério Público não poderá desistir da ação penal.

O artigo 385, do Código de Processo Penal está redigido no sentido de que nos crimes de ação pública, o juiz poderá proferir sentença condenatória, ainda que o Ministério Público tenha opinado pela absolvição, bem como reconhecer agravantes, embora nenhuma tenha sido alegada. 
De acordo com Araújo e Costa (2020), o artigo 385, do Código de Processo Penal tratou apenas da ação penal de natureza pública, porque, caso se trate de ação penal de iniciativa privada e o querelante não requeira, em sede alegações finais, a condenação do querelado, restará caracterizada a perempção com esteio no artigo 60, inciso III, do Código de Processo Penal, uma vez que atua de conformidade com o princípio da oportunidade, e, se não pedir a condenação, não poderá o juiz decidir contrariamente ao seu desejo.

Como se depreende da leitura dos autores citados, o membro do Ministério Público possui independência funcional, vale dizer, independência de atuação, com fundamento no artigo $127, \S 1^{\circ}$, da Constituição Federal de modo que não está vinculado ao pedido condenatório inicialmente feito.

Dessarte, Araújo e Costa (2020) destacam que muito embora o promotor tenha pedido, na denúncia, a condenação do agente, poderá, ao fim da instrução penal, se estiver convencido da inocência do acusado, requerer a absolvição.

Na jurisprudência das Cortes pesquisadas encontramos exemplo de casos em que promotor diverso daquele que havia oferecido a denúncia posicionou-se pela absolvição nas alegações finais, sem que isso seja compreendido como ofensa à independência funcional ou ao princípio da indisponibilidade da ação penal pública.

Cumpre lembrar que o Código de Processo Penal Militar, no artigo 437, letra b, prescreveu que o Conselho de Justiça poderá proferir sentença condenatória por fato articulado na denúncia, não obstante haver o Ministério Público opinado pela absolvição, bem como reconhecer agravante objetiva, ainda que nenhuma tenha sido arguida.

O artigo 576, do Código de Processo Penal previu que o Ministério Público não poderá desistir de recurso que haja interposto. Idêntica é a redação do artigo 512, do Código de Processo Penal Militar. Trata-se do mesmo desdobramento dos princípios da obrigatoriedade e da indisponibilidade para a fase recursal.

De acordo com Dezem (2020) no contexto da história processual penal foram 3 (três) os sistemas desenvolvidos para orientar o jus puniendi o sistema acusatório, o sistema inquisitivo e o sistema misto. Ainda de acordo com o autor, no âmbito doutrinário brasileiro 
especula-se 2 (dois) questionamentos: Qual é o sistema adotado no Brasil ? e O que caracteriza cada um dos sistemas?

Desse modo, para responder aos questionamentos acima, se apresenta com premissa necessária na compreensão do termo sistema, uma vez que possui conteúdo polissêmico. A palavra sistema, segundo Dezem (2020) tem origem nos termos gregos systema e synistanai, cujo significado é juntar.

Apesar do esforço inicial para buscar uma uniformidade de definição, segue admitirmos que não existe uniformidade na doutrina, uma vez que para Bobbio (1999) a palavra sistema tem o sinônimo de ordenamento jurídico. Seguindo outra senda, Coutinho (2001), a palavra sistema vem designar um conjunto de temas colocados em relação por um princípio unificador, que forma um todo pretensamente orgânico, destinado a uma finalidade, o que também é defendido por Martins (2010), que prefere chamar esse fio de condutor de princípio regente.

De acordo com Fonseca (2013):

"Os termos sistema e princípio não devem ser confundidos ou utilizados como se representassem a mesma ideia. Sistema significa o conjunto de elementos ou princípios destinados a formar um todo orgânico, e princípio nos transmite a ideia de algo que surge com anterioridade. A relação existente entre sistema e princípio seria de continente e conteúdo, respectivamente, já que os sistemas são formados por princípios." (destacamos)

A grande controvérsia existente é justamente perquirir qual seria(m) os elementos unificadores do sistema acusatório, de modo a caracterizá-lo e diferenciá-lo do sistema inquisitivo, resolução que facilitariam responder aos dois questionamentos acima. Nesse caminho lógico, ressalta Fonseca (2013) que os sistemas processuais penais são definidos como subsistemas jurídicos, que são formados pela reunião, ordenada e unificada, de elementos fixos e variáveis. Os primeiros criam e identificam o sistema ao passo que os demais permitem o funcionamento e a mobilidade desse sistema.

Ainda de acordo com o autor:

"Os diferentes sistemas processuais penais contêm dois elementos fixos: um de ordem principiológica e, outro de ordem procedimental. 
O elemento de ordem principiológica está relacionado ao princípio reitor de cada sistema, mais especificamente à importância atribuída à figura do acusador. Nos sistemas processuais penais, cumprem essa função o princípio acusatório e o princípio inquisitivo. Assim, o princípio acusatório exige a presença obrigatória de um acusador distinto do juiz em todo um modelo de processo. Já o princípio inquisitivo representa o caráter prescindível de um acusador distinto do juiz em todo um modelo de processo, e não em um determinado processo in concreto.

O elemento de ordem procedimental se refere ao fator ou fatores que, em cada sistema, são determinantes para a abertura do processo judicial de natureza punitiva.” (FONSECA, 2013, p. 479-480).

Do ponto de vista histórico, não existem sistemas processuais puros, muito menos um critério da identificar a pureza de um desses sistemas, uma vez que, como pontua Fonseca (2013), os sistemas processuais penais não possuem linearidade, muito menos características rígidas que não pudessem sobreviver conjuntamente em um determinado contexto.

Desse desenvolvimento histórico, cujo estudo aprofundado foge aos objetivos do presente artigo, podemos extrair as seguintes características para o sistema acusatório:

a) A jurisdição é exercida por tribunais populares;

b) A persecução penal é exercida por pessoa física;

c) O acusado é sujeito de direitos;

d) O processo é público, oral e contraditório;

e) A valoração das provas é realizada pelo sistema do livre convencimento motivado; e

f) Existe a separação das funções de acusar e julgar.

Por sua vez, o sistema inquisitivo teria as seguintes características:

a) Hierarquização da jurisdição;

b) Ausência de separação de funções, sendo o juiz responsável pela investigação, acusação e julgamento.

c) O acusado é mero objeto da persecução penal;

d) O processo era sigiloso e escrito; 
e) A valoração das provas era feito por meio do chamado sistema da prova legal ou tarifada.

De acordo com a doutrina, a rigor, não existem sistemas processuais penais puros, uma vez que alguns países se aproximam mais ou menos de um deles. Um dos países que é apontado como um exemplo de sistema acusatório puro é o sistema processual penal inglês, assim como os Estados Unidos.

De acordo com estudos do Centros de Estudos Jurídicos Americanos (2019) vários países latino-americanos promoveram reformas nos seus sistemas processuais penais de modo a adotar sistema acusatório puro, podendo ser citados, dentre outros, os seguintes: Uruguai; Chile; Colômbia e Argentina.

Ainda de acordo com essa pesquisa, o Brasil é o único país latino-americano que ainda não reformou integralmente seu Código de Processo Penal, optando por fazer reformas pontuais na legislação processual penal sendo que a Lei $\mathrm{n}^{\mathrm{o}}$ 13.694/2019, apontou expressamente na direção idêntica aos países citados.

De fato, na mesma ordem de ideias, temos lembrança ainda do Projeto de Lei $n^{\circ}$ 8.045/2010, referente ao Projeto do Novo Código de Processo Penal, onde houve por bem a Comissão de Juristas, formada no Senado Federal, reconhecer avanço nessa matéria. Com efeito, o artigo 450, do Projeto não repetiu a norma do artigo 385, do vestuto Código de Processo Penal, contudo permite ao magistrado condenar caso o assistente da acusação, neste caso o ofendido, se manifeste pela acusação. Eis os termos:

Art. 450. O juiz proferirá sentença condenatória, nos estritos limites da peça acusatória. Manifestando-se o Ministério Público pela absolvição, não poderá o juiz condenar nem reconhecer agravante não alegada ou causa de aumento não imputada.

Parágrafo único. Havendo requerimento condenatório do assistente de acusação, não se aplica a segunda parte do caput. (grifei)

De fato, percebe-se que o projeto, em que pese a titularidade da ação penal pública pertencer, de acordo com o texto magno, ao Ministério Público, busca-se harmonizar 
o postulado garantista com a busca por justiça e a própria eficiência do sistema processo penal.

De fato, a previsão do parágrafo único do Projeto do Novo Código de Processo Penal demonstra um caminho possível, uma vez que consagra mais um mecanismo de controle da opinio delicti do Ministério Público, desta vez, ao término da instrução processual, de igual modo como é a diretriz a respeito do arquivamento do inquérito policial, hoje prevista na nova redação do artigo 28, do Código de Processo Penal.

Ocorre que, como sabido, nem todas as infrações penais possuem sujeito passivo mediato, portanto não terão ofendido, cabendo citar crimes como o tráfico de drogas (artigo 33, da Lei $\left.n^{\circ} 11.343 / 2006\right)$. Por outro lado, ainda que haja um ofendido direito da infração penal, nem sempre esta será diligente e estará devidamente representada no processo penal de modo a requerer aquilo que for do seu interesse.

Em que pese tais apontamentos, inclusive de lege ferenda, a doutrina brasileira majoritária e a jurisprudência, como acima visto, ainda se posicionam pela constitucionalidade do artigo 385, do Código de Processo Penal, vale dizer, por sua compatibilidade com o sistema acusatório, não havendo que falar que esta norma não teria sido recepcionada pela nova ordem constitucional.

Com efeito, importante mencionar que mesmo antes da alteração legislativa mencionada neste trabalho, na doutrina nacional releva citar posicionamento que se insurge contra a constitucionalidade do artigo 385, do Código de Processo Penal importando citar Freire Jr (2005), Lopes Jr (2020), Rangel (2020), Thums (2012), Queiroz (2012), dentre outros.

Sobre a relativização do princípio da obrigatoriedade da ação penal, em interessante artigo doutrinário Melo (2020), enfatizou que a oportunidade da ação penal não gera impunidade, mas eficiência, bem como está em conformidade com o princípio constitucional da independência funcional do membro do Ministério Público.

Por outro lado, Melo (2020), endossa que o artigo 28, do Código de Processo Penal não delimitou adequadamente as razões do pedido de arquivamento do inquérito policial ou peças de informação, o que portanto pode ser feito por política criminal e, até 
mesmo, aventada a possibilidade do arquivamento provisório por prioridades em analogia ao artigo 18, do Código de Processo Penal, uma vez que não tem a palavra “definitivo".

Defende ainda o ilustre Promotor de Justiça de Minas Gerais que a obrigatoriedade da ação penal não é um princípio, nem está positivado em nosso ordenamento jurídico e, mesmo que estivesse, seria uma regra ou um mito, podendo ser acoimada de inconstitucional por ofensa a independência funcional dos membros do Ministério Público e à autonomia do órgão ministerial para estabelecer as prioridades para usar os seus recursos orçamentários (MELO, 2020, p. 232-233).

\section{NECESSIDADE DE REFLEXÃO E MUDANÇA DA JURISPRUDÊNCIA}

De acordo com Damaska (1986), a oposição existente entre os sistemas acusatório (adversarial) e inquisitório é deveras fluída a partir de determinado ponto, uma vez que essa dicotomia é bem mais complexa do que as vezes costuma parecer.

Nesse ponto, alerta-nos Damaska (1986) que devem ser tomados cuidados com visões extremadas da concepção do que seja acusatório e do que seja inquisitivo, pois fora do princípio de distinção (separação de funções) as semelhanças são evidentes. De outro modo, alerta-nos que não devem ser banalizados os termos inquisitivo e acusatório.

O mesmo pensamento é externado por Fonseca (2013) em grandiosa obra sobre o tema, concluindo que as características variáveis de cada um dos sistemas não são suficientes para concluir quanto a adoção de um ou outro desses sistemas.

Em que pese possuir julgados no Superior Tribunal de Justiça relatados pelo Ministro Reynaldo Soares da Fonseca favoráveis a manutenção da regra ora analisada, sua Excelência alertou recentemente em palestra ocorrida no Programa de Pós Graduação da Universidade Federal do Maranhão, no dia 18/12/2020, disponível na página do programa no YOUTUBE, sobre as repercussões do pacote anticrime em diversos artigos do Código de Processo Penal que não foram expressamente revogados, havendo expectativa que a doutrina 
e a jurisprudência façam interpretações necessárias as adequações para harmonização do sistema.

Ora a jurisprudência apontada não fez uma análise crítica do contexto de transformações sofridos pelo processo penal brasileiro, com destaque para o novo papel do Ministério Público como titular da ação penal pública. O posicionamento do Ministério Público em sede de alegações, como defendido por Fernandes (2007) e Lopes Jr (2019), não se trata de mera opinião do órgão acusador.

Não se pode negar que o aumento dos espaços de consenso no processo penal culminou na mitigação do princípio da obrigatoriedade e disponibilidade da ação penal, ampliando a margem de discricionariedade do órgão acusador para, dentro do escopo legal dos novos institutos (transação penal, colaboração premiada, acordo de não persecução penal, acordo de leniência, acordo de não persecução civil) delinear um sistema muito mais próximo do sistema adversarial inglês ou americano.

Desse modo, como advertido pelo Ministro Rogério Schietti, no julgamento do REsp 1.521.239 / MG, no Brasil não dispunha o ministério público de poderes iguais ao prosecutor norte americano, ocorre que hodiernamente não se pode mais sustentar esse posicionamento.

Correto observar que desde a Constituição Federal de 1988 que a legislação infraconstitucional foi aperfeiçoando mecanismos no sistema processual penal de modo a aproximar-se cada vez mais do parâmetro acusatório desenhado pelo constituinte, inexistindo uma incompatibilidade material do pensamento ora alinhado com aquele.

É de bom alvitre ainda lembrar com Vieira (2017) a ideia de que a condenação de um acusado, após manifestação de absolvição pelo órgão do Ministério Público, ao cabo da instrução processual penal, ofende não somente o princípio acusatório, como também os princípios do contraditório e da ampla defesa.

Considera Vieira (2017), muito embora o avanço do debate em sede doutrinária e, diríamos jurisprudencial, como acima se destaca, as alegações finais do Ministério Público não devem ser consideradas como um mero parecer e demonstrou que a norma objeto de questionamento somente teria aplicabilidade partindo-se do pressuposto do princípio da 
verdade real, que disse ser insustentável, tanto do ponto de vista epistemológico quanto político-jurídico.

De fato, defendeu Vieira (2017) que o princípio acusatório vedará o magistrado de substituir o órgão de acusação quando houver abandono por parte deste da acusação que sustente eventual condenação.

A incoerência epistemológica encontra razão de ser. Bem visto o fundamento dos acórdãos objeto de nossa pesquisa, percebe-se que se escoram no princípio do livre convencimento motivado. Ora trata-se de um princípio ligado à liberdade que o magistrado possui para julgar o processo e legitimar esse julgamento, corolário do disposto no artigo 92, inciso IX, da Constituição Federal de 1988.

Trata-se de uma característica que não é exclusiva do sistema acusatório, como leciona Andrade (2013), inexistindo vinculação deste como elemento fixo ou característica qualificadora do sistema acusatório.

\section{CONCLUSÃO}

À guisa de conclusão, percebe-se a necessidade de refletir acerca da titularidade da ação penal pública pelo Ministério Público em paralelo aos interesses da vítima e a eficiência do sistema processual penal, sem descurar das garantias do acusado.

Nesse passo, para manutenção da necessária imparcialidade do órgão julgador e coerência epistemológica do sistema de apreciação da prova, não mais preso ao postulado da verdade real, urge enfrentar o tema da vinculação do magistrado à retirada da acusação pelo Ministério Público em sede de alegações finais, do mesmo modo como caracterizaria perempção nas ações penais privadas, a concluir pela extinção da punibilidade ou mesmo absolvição do acusado.

Em que pese não termos um sistema acusatório puro, mister reconhecer a necessidade do nosso processo penal aproximar-se de um modelo processual de partes ou adversarial, próprio e com as peculiaridades do nosso sistema, não necessariamente copiando 
um modelo estrangeiro com uma carga cultural e problemas que não são os mesmos enfrentados pelo nosso Poder Judiciário.

Com a modificação proposta pelo pacote anticrime urge seguir na compreensão de que o artigo 385, do Código de Processo Penal foi revogado tacitamente, por incompatibilidade com o modelo acusatório delineado, o que se propõe à reflexão especialmente dos Tribunais de vértice.

\section{REFERÊNCIAS BIBLIOGRÁFICAS}

ANDRADE, Mauro Fonseca. Sistemas Processuais Penais e seus princípios reitores. $2^{\mathrm{a}}$ ed. rev. e ampl. Curitiba: Juruá, 2013.

ARAÚJO, Fábio Roque. COSTA, Klaus Negri. Processo Penal didático. $3^{\mathrm{a}}$ ed. rev. atual. e ampl. Salvador: Juspodivm. 2020.

BADARÓ, Gustavo Henrique. Correlação entre acusação e sentença. $4^{\mathrm{a}}$ ed. rev. atual. e ampl. São Paulo: Revista dos Tribunais, 2019.

BENTIVEGNA, Carlos Frederico Barbosa. Liberdade de expressão, honra, imagem e privacidade: Os limites entre o lícito e o ilícito. Barueri: Manole, 2020

BRASIL. Constituição da República Federativa do Brasil. Diário Oficial da União. Poder Legislativo. Brasília, DF, 5 out. 1988, 191-A, p. 1

., Decreto-lei no 2.848, de 31 de dezembro de 1940. Código Penal. Diário Oficial da União. Poder Legislativo. Brasília, DF, 31 dez. 1941, p. 2391. Retificação: DOFC de 03/01/1941.

, Decreto-lei no 3.689, de 3 de outubro de 1941. Código de Processo Penal.

Diário Oficial da União. Poder Legislativo. Brasília, DF, 13 out. 1941, p. 2391. Retificação: DOFC de 24/10/1941.

, Lei n ${ }^{\circ}$ 9.099, de 26 de setembro de 1995. Dispõe sobre os Juizados Especiais Cíveis e Criminais e dá outras providências. Diário Oficial da União. Poder Legislativo. Brasília, DF, DOFC de 27/09/1995.

., Lei $\mathrm{n}^{\circ} 12.850$, de 2 de agosto de 2013. Define organização criminosa e dispõe sobre a investigação criminal, os meios de obtenção da prova, infrações penais correlatas e o procedimento criminal; altera o Decreto-lei n ${ }^{\circ} 2.848$, de 7 de dezembro de 1940 (Código Penal); revoga a Lei no 9.034, de 3 de maio de 1995; e dá outras providências. Diário Oficial da União. Poder Legislativo. Brasília, DF, DOFC de 5/08/2013. 
., Lei no 13.964, de 24 de dezembro de 2019. Aperfeiçoa a legislação penal e processual penal. Diário Oficial da União. Poder Legislativo. Brasília, DF, DOFC de 24/12/2019. p. 1. Edição extra.

.,. Supremo Tribunal Federal. Decisão monocrática. ADI's 6.298, 6.299, 6.300 e

6.305. Relator Ministro Luiz Fux. Brasília, DF, julgamento em 22 jan. 2020. DJ 29 maio 2014.

. Supremo Tribunal Federal. Primeira Turma. AgR no HC no $185.835 / \mathrm{SP}$, Relator Ministro Alexandre de Moraes. Brasília, DF, Sessão virtual. Julgamento de 26 de jun. a 4 ago. 2020.

. Superior Tribunal de Justiça. Quinta Turma. AgRg nos EDcl no HC 537251 /

SP, Relator Ministro Néfi Cordeiro. Brasília, DF, julgamento em 12 mai. 2020.

CARNELUTTI, Francesco. As misérias do Processo Penal. Tradutora Isabela Cristina Sierra. $2^{a}$ ed. Sorocaba: Editora Minelli, 2006.

DAMASKA, Mirjan R. The faces of justice and state authority: a comparative approach to the legal process. London: Yale University Press, 1986 (versão e-book kindle).

DEZEM, Guilherme Madeira. Curso de Processo Penal. $6^{a}$ ed. rev. atual. e ampl. São Paulo: Revista dos Tribunais, 2020.

FERNANDES, Antonio Scarance. Processo Penal Constitucional. $5^{\mathrm{a}}$ ed. rev. atual. e ampl. São Paulo: Revista dos Tribunais, 2007.

FREIRE Jr. Américo Bedê. Da Impossibilidade do Juiz Condenar Quando Há o Pedido de Absolvição Formulado pelo Ministério Público. Boletim do IBCCRIM, nº 152 - julho 2005.

GARCIA, Rafael D. Verdade Real e a Impossibilidade de Condenação após Manifestação do Ministério Público por Absolvição. Revista Brasileira de Direito Processual Penal, Porto Alegre, vol. 3, n. 3, p. 1043-1070, set./dez. 2017. https://doi.org/10.22197/rbdpp.v3i3.81 (acesso em 20 de dezembro de 2020)

GOLDSCHMIDT, James. Problemas jurídicos e políticos do Processo Penal. Tradução Mauro Fonseca de Andrade e Mateus Marques. Porto Alegre: Livraria do Advogado editora, 2018.

LIMA, Renato Brasileiro de. Manual de Processo Penal. Volume único. $8^{\mathrm{a}}$ ed. rev. atual. e ampl. Salvador: Jus Podivm, 2020.

LOPES Jr., Aury. Fundamentos do Processo Penal: Introdução crítica. $5^{a}$ ed. São Paulo: Saraiva, 2019.

MELO, André Luís Alves de. Da não obrigatoriedade da ação penal pública. In: CUNHA, Rogério Sanches., et al. Acordo de não persecução penal. Salvador: JUspodivm, 2017, p. 191234. 
NUCCI, Guilherme de Souza. Pacote anticrime comentado. Rio de Janeiro: Forense, 2020.

PACELLI, Eugênio. FISCHER, Douglas. Comentários ao Código de Processo Penal e sua jurisprudência. $11^{\mathrm{a}}$ ed. rev. atual. e ampl. São Paulo: Atlas, 2019.

PINTO, Felipe Martins. Introdução Crítica ao Processo Penal. 2a ed. Belo Horizonte: Del Rey, 2016.

RANGEL, Paulo. Direito Processual Penal. $28^{\mathrm{a}}$ ed. rev. atual. e ampl. São Paulo: Atlas, 2020.

SILVEIRA FILHO, Sylvio Lourenço da. Introdução ao Direito Processual Penal. $2^{a}$ ed. Florianópolis: Empório do Direito, 2015.

SOUZA, João Fiorillo de. A iniciativa instrutória do juiz e o sistema processual penal brasileiro: uma abordagem a partir do garantismo de Luigi Ferrajoli. Curitiba: Juruá, 2013.

TOURINHO FILHO, Fernando da Costa. Manual de Processo Penal. $18^{\mathrm{a}}$ ed. rev. e atual. São Paulo: Saraiva, 2018.

WEDY, Miguel Tedesco; LINHARES, Raul Marques. Processo Penal e História - A origem dos sistemas processuais-penais acusatório e inquisitivo. Revista Brasileira de Ciências Criminais. vol. 114. ano 23. p. 379-412. São Paulo: Ed. RT, maio-jun. 2015. 